\title{
Konwergencja w krajach byłego Związku Radzieckiego w okresie 1991-2010
}

Zarys treści: Niniejszy artykuł weryfikuje hipotezę konwergencji w grupie 15 państw byłego Związku Radzieckiego. W pierwszej części artykułu wyszczególniono i scharakteryzowano różne typy konwergencji, przede wszystkim typu $\beta$ i $\sigma$, które zostały poddane weryfikacji empirycznej w dalszej części artykułu. Następnie dokonano przeglądu dotychczasowych badań, zaprezentowano zastosowaną metodologię i próbę badawczą oraz przedstawiono wyniki analizy regresji. Badanie przeprowadzono dla całego okresu 1991-2010 i z podziałem na kilka podokresów.

Outline of content: The article verifies the convergence hypothesis within 15 former Soviet Union countries. The first part of the article lists and characterizes different types of convergence, focusing mainly on $\beta$ - and $\sigma$-convergence, which are verified in the next part of the text. Next, there is an overview of the current state of research, a description of the research methodology and research sample, together with a presentation of the analysis results. The analysis was conducted for the whole period of 1991-2010, and with a division into subperiods.

Słowa kluczowe: konwergencja, Związek Radziecki, PKB per capita

Keywords: convergence, Soviet Union, GDP per capita

\section{Wprowadzenie}

26 grudnia 1991 r. nastąpiło formalne rozwiązanie Związku Socjalistycznych Republik Radzieckich. Było to przełomowe wydarzenie w historii Europy i świata, kończące epokę zimnej wojny. 15 republik ZSRR uzyskało niezależność. Zmianom politycznym towarzyszyły zmiany w sferze gospodarczej. Nowo powstałe państwa musiały stawić czoła nowej sytuacji, dążąc do transformacji modelu gospodarczego w kierunku gospodarki rynkowej. Tempo i charakter tych zmian, jak i ich efekty były bardzo zróżnicowane w poszczególnych krajach. W początkowym okresie 
wszystkie państwa zanotowały spadek produkcji. Różna jednak była długość i głębokość recesji. Część państw relatywnie szybko wkroczyła na ścieżkę wzrostu gospodarczego, inne zaś doświadczyły długotrwałej recesji. Trzy państwa bałtyckie, tj. Litwa, Łotwa i Estonia, zdołały dołączyć do Organizacji Współpracy Gospodarczej i Rozwoju (ang. Organisation for Economic Co-operation and Development OECD), grupującej państwa wysokorozwinięte. Na przeciwległym biegunie znajduje się Ukraina, Tadżykistan i Mołdawia, które do dnia dzisiejszego nie osiągnęły poziomu PKB per capita z $1990 \mathrm{r}$.

Celem artykułu jest weryfikacja hipotezy o występowaniu konwergencji poziomów dochodu per capita w grupie 15 państw powstałych po upadku ZSRR. W analizie uwzględnione zostały dwa rodzaje konwergencji: konwergencja absolutna typu $\beta$ oraz konwergencja typu $\sigma$. Analizie poddano okres pomiędzy 1991 a 2010 r. oraz kilka krótszych podokresów.

\section{Teoretyczne ujęcie zjawiska konwergencji}

Z terminem "konwergencja” możemy spotkać się w wielu dziedzinach nauki. W ujęciu ogólnym oznacza on powstawanie zbieżności. W ujęciu ekonomicznym termin ten jest rozumiany zazwyczaj jako hipoteza mówiąca o tym, iż kraje biedniejsze osiągają wyższe stopy wzrostu produkcji na mieszkańca, niż kraje bogatsze. $\mathrm{W}$ perspektywie długookresowej prowadzi to do zanikania różnic w poziomach dochodu między poszczególnymi gospodarkami. Hipoteza tak rozumianej konwergencji opiera się na neoklasycznej teorii wzrostu gospodarczego. Na występowanie zbieżności poziomów dochodu per capita między gospodarkami wskazuje model Solowa. Model zakłada zbieżność gospodarek i ich ścieżek wzrostu zrównoważonego. Tendencja do zbieżności wynika $\mathrm{z}$ tego, iż poszczególne gospodarki znajdują się w różnej odległości od swoich ścieżek zrównoważonego wzrostu. Co więcej, poziom zasobów kapitałowych przypadających na jednego zatrudnionego jest niższy w krajach uboższych. Stopa przychodowości kapitału w tych krajach jest więc wyższa, co stanowi bodziec stymulujący przepływ kapitału z krajów bogatszych do krajów biedniejszych. Zakłada się również, że wiedza nie dociera w sposób jednoczesny i równomierny do wszystkich gospodarek. Tym samym zawsze istnieją kraje, które jeszcze nie mają dostępu do najwyższej technologii. Transfer technologii do tych gospodarek spowoduje więc przyspieszenie wzrostu ${ }^{1}$.

Model Solowa wskazuje na istnienie konwergencji warunkowej. Zbieżność jest warunkowa, gdyż dla każdej gospodarki poziom produkcji per capita w jej stanie stacjonarnym jest odmienny. Występowanie konwergencji warunkowej przewidują również inne modele wzrostu egzogenicznego, jak np. model Ramseya-Cassa-Kopmansa oraz model Mankiwa-Romera-Waila. Różne jest jednak tempo

${ }^{1}$ D. Romer, Makroekonomia dla zaawansowanych, Warszawa 2000. 
konwergencji implikowane przez poszczególne modele. Na istnienie zbieżności poziomów dochodu nie wskazuje natomiast model $\mathrm{AK}$, należący do grupy endogenicznych modeli wzrostu. Zgodnie z założeniami modelu stopa wzrostu kapitału na pracownika jest stała i równa stopie wzrostu produkcji na pracownika. Nie zachodzi zjawisko konwergencji, rozumiane jako zbieżność gospodarki do stanu stacjonarnego, ponieważ gospodarka zawsze znajduje się w stanie wzrostu zrównoważonego. Konwergencja nie występuje również w modelu Lucasa. W tym ujęciu istnieje nieskończenie wiele stanów stacjonarnych, a każda gospodarka zmierza do jednego z nich. Gospodarki o niskim początkowym poziomie kapitału dążą do stanu ustalonego, w którym poziom kapitału jest również niski. Gospodarki o wyższym początkowym poziomie kapitału osiągają równowagę w punktach, gdzie poziom kapitału jest wyższy. Każdy stan stacjonarny charakteryzuje się takim samym tempem wzrostu gospodarczego, dlatego różnice w poziomach dochodu nie zanikają ${ }^{2}$.

Jeden $\mathrm{z}$ obszarów badawczych $\mathrm{w}$ zakresie problematyki konwergencji stanowi poszukiwanie przyczyn powstawania zbieżności gospodarek. Odpowiedź na pytanie o przyczyny konwergencji nie jest prosta i jednoznaczna. Funkcjonuje wiele różnych stanowisk $\mathrm{w}$ tym obszarze. Jedna $\mathrm{z}$ teorii zakłada, iż konwergencja zależy jedynie od akumulacji kapitału. Technologia nie odgrywa żadnej roli, ponieważ nie występuje technologiczne zróżnicowanie pomiędzy poszczególnymi regionami ${ }^{3}$. Robert E. Lucas stwierdził jednak, iż to właśnie dyfuzja technologii stanowi główny czynnik warunkujący zachodzenie procesów zbieżności gospodarek ${ }^{4}$. Za kompromisowe można uznać stanowisko, zgodnie z którym na konwergencję mają wpływ zarówno akumulacja kapitału, jak i transfer technologii ${ }^{5}$.

Rozwój badań nad konwergencją doprowadził do powstania licznych koncepcji w tym obszarze, jak również kilku odmiennych metod testowania hipotezy konwergencji. Funkcjonujące w literaturze typy konwergencji możemy podzielić na klasyczne koncepcje konwergencji oraz pozostałe koncepcje konwergencji. Do koncepcji klasycznych zaliczamy konwergencje typu: $\beta, \gamma, \sigma$. Wśród pozostałych koncepcji konwergencji możemy wyróżnić np. konwergencje stochastyczną i technologiczną. W niniejszym artykule weryfikacja hipotezy badawczej dokonana zostanie za pomocą testowania absolutnej $\beta$-konwergencji oraz $\sigma$-konwergencji.

Koncepcja konwergencji typu $\beta$ opiera się na założeniu występowania malejących przychodów krańcowych z kapitału, co oznacza, że wyższa produktywność krańcowa występuje w krajach uboższych w kapitał. Implikacją tego założenia jest przyjęcie twierdzenia o występowaniu ujemnej zależności korelacyjnej pomiędzy stopą

2 Ibidem.

3 N.G. Mankiw, D. Romer, D.N. Weil, A Contribution to the Empirics of Economic Growth, „Quarterly Journal of Economics" (1992), nr 107.

4 R.E. Lucas, Some Macroeconomics for the 21st Century, „Journal of Economic Perspective” (2000), nr 14 (1).

5 F. Pigliaru, Detecting Technological Catch-Up in Economic Convergence, „Metroeconomica” (2003), nr $54(2 / 3)$. 
wzrostu PKB per capita a poziomem tej zmiennej na początku badanego okresu. Tak rozumianą konwergencję testuje się za pomocą następującego równania regresji:

$$
\frac{1}{T} \ln \frac{Y_{i T}}{Y_{i 0}}=\alpha_{0}+\alpha_{1} \ln Y_{i T}+\varepsilon_{i T}
$$

gdzie:

$\frac{1}{T} \ln \frac{Y_{i T}}{Y_{i 0}}-$ średnia stopa wzrostu PKB per capita w kraju

$\alpha_{0}, \alpha_{1}-$ współczynniki regresji

$Y_{i 0}-$ początkowy poziom PKB per capita

$\varepsilon_{i t}$ - szereg zmiennych losowych.

Warunkiem zaistnienia konwergencji w tym ujęciu jest dodatnia wartość współczynnika $\alpha_{1}$. Im wartość współczynnika bliższa jedności, tym wyraźniejsza tendencja do występowania konwergencji absolutnej. Pozytywna weryfikacja hipotezy o występowaniu $\beta$-konwergencji pozwala wyznaczyć tempo zbieżności. Wzór na współczynnik $\beta$ informujący o tempie zbieżności przyjmuje następującą postać:

$$
\beta=-\frac{1}{T} \ln \left(1+\alpha_{1} T\right)
$$

Odmiennym typem konwergencji jest konwergencja typu o. Podziału na konwergencję typu $\beta$ i $\sigma$ jako pierwszy dokonał w swojej pracy doktorskiej Xavier X. Sala-i-Martin ${ }^{6}$. Zgodnie z zaproponowaną przez niego definicją z $\sigma$-konwergencją mamy do czynienia wtedy, gdy z okresu na okres zmniejsza się dyspersja poziomów PKB per capita w badanej grupie gospodarek. Do badania poziomu dyspersji stosuje się takie miary, jak odchylenie standardowe oraz wariancja logarytmu PKB per capita. Wzór na odchylenie standardowe logarytmu naturalnego PKB per capita przyjmuje następującą postać:

$$
\sigma(\mathrm{t})=\sqrt{\frac{1}{n}} \sum_{i=1}^{n}\left(\ln y_{i}-\breve{y}(t)\right)^{2}
$$

gdzie:

$\breve{y}(t)=\frac{1}{n} \sum_{i=1}^{n} \ln y_{i}(t)$

Konwergencja typu $\sigma$ zachodzi, gdy spełniona jest nierówność:

$$
\sigma(\mathrm{t})<\sigma(\mathrm{t}-1)
$$

Spełnienie tej nierówności oznacza, iż w porównaniu z poprzednim okresem doszło do zmniejszenia się dyspersji poziomów PKB per capita $\mathrm{w}$ badanej grupie gospodarek. Tym samym mamy do czynienia z zaistnieniem $\sigma$-konwergencji ${ }^{7}$.

\footnotetext{
${ }^{6}$ X.X. Sala-i-Martin, On Growth and States, Cambridge 1990.

7 Idem, The Classical Approach to Convergence Analysis, „Economic Journal” 106 (1996), nr 437.
} 
Metodą weryfikacji hipotezy o występowaniu konwergencji typu $\sigma$ jest oszacowanie parametrów następującego równania regresji:

gdzie:

$$
S D(\ln y(t))=\alpha_{0}+\alpha_{1} t
$$

$S D(\ln y(t))$ - odchylenie standardowe logarytmu naturalnego poziomu PKB per capita w badanej grupie gospodarek

$\mathrm{t}$ - kolejne następujące po sobie okresy $(\mathrm{t}=1,2,3, \ldots)$

\section{Przegląd literatury}

Hipoteza konwergencji jest poddawana weryfikacji w wielu badaniach prowadzonych przez ekonomistów. Intensyfikacja badań w tym obszarze nastąpiła w latach osiemdziesiątych i dziewięćdziesiątych XX w. Debatę nad problematyką konwergencji zapoczątkowało pojawienie się publikacji Williama J. Baumola w $1987 \mathrm{r}$. Operował on na próbie 16 krajów uprzemysłowionych ${ }^{8}$. Punktem odniesienia stał się poziom dochodu per capita z 1870 r., natomiast średnia stopa wzrostu została skalkulowana dla następnych 110 lat, a więc dla okresu 1870-1980. Badanie przeprowadzone przez Baumola wykazało istnienie silnej ujemnej korelacji między początkowym poziomem dochodu per capita a stopą wzrostu osiąganą w następnym okresie. Robert J. Barro analizował wpływ szeregu czynników na wzrost gospodarczy, w tym również poziomu PKB per capita na początku okresu' ${ }^{9}$. Wykazał, iż prosta korelacja pomiędzy początkowym poziomem produkcji per capita a stopą wzrostu gospodarczego w następnym okresie jest bardzo słaba. Udowodnił natomiast bardzo silną zależność między osiąganą stopą wzrostu a poziomem kapitału ludzkiego. Co istotne, w swych badaniach Barro posługiwał się danymi dla innych krajów, odnoszącymi się do innego okresu niż w przypadku pracy Baumola. Ważny wkład do badań nad zagadnieniem konwergencji wniósł Sala-i-Martin. Na szczególną uwagę zasługują jego dwie prace osadzone w tej problematyce, opublikowane w latach 1992 i 1994. Barro i Sala-i-Martin dokonali weryfikacji hipotezy konwergencji, bazując na próbie badawczej składającej się z 48 stanów $\mathrm{USA}^{10}$. Uwzględniając $\mathrm{w}$ analizach dane $\mathrm{z}$ lat 1840-1988, wykazali występowanie ujemnej statystycznie istotnej relacji pomiędzy początkowym poziomem dochodu per capita a średnioroczną stopą wzrostu, skalkulowaną dla tego okresu. W pracy opublikowanej dwa lata później Sala-i-Martin dokonał kolejnej pozytywnej weryfikacji hipotezy konwergencji, szacując tempo zbieżności na ok. $2 \%$ rocznie $^{11}$.

8 W.J. Baumol, Productivity Growth, Convergence, and Welfare, "American Economic Review” 76 (1986), nr 5.

9 R.J. Barro, Economic Growth in a Cross Section of Countries, „Quarterly Journal of Economics” 106 (1991), nr 2.

10 R.J. Barro, X.X. Sala-i-Martin, Convergence, „Journal of Political Economy” 100 (1992), nr 2.

11 X.X. Sala-i-Martin, Cross-sectional Regressions and the Empirics of Economic Growth, „European Economic Review" 38 (1994), nr 3-4. 
W literaturze możemy znaleźć jednak bardzo wiele publikacji krytycznie odnoszących się do hipotezy konwergencji. Już rok po opublikowaniu pracy Baumola konwergencja została poddana krytyce przez J. Bradforda De Longa. Stwierdził on, że pozytywna weryfikacja hipotezy konwergencji jest uwarunkowana arbitralnym doborem próby badawczej, a jej rozszerzenie prowadzi do podważenia wcześniej wyciągniętych wniosków ${ }^{12}$. Hipoteza o występowaniu konwergencji w skali globalnej została podana w wątpliwość przez Paula M. Romera ${ }^{13}$. W oparciu o próbę badawczą składającą się z 115 krajów dokonał on regresji średniorocznej stopy wzrostu dla okresu 1960-1981 względem poziomu PKB per capita w 1960 r. Badanie nie wykazało istnienia ujemnej relacji między owymi zmiennymi, a więc hipoteza konwergencji nie została potwierdzona. Thorkil Kristensen uszeregował badane gospodarki względem poziomu PKB per capita z 1974 r. ${ }^{14}$ Analizując stopy wzrostu tych gospodarek w okresie 1970-1980, zauważył, że najszybciej w tym okresie rozwijały się kraje znajdujące się na poziomie średniego dochodu. Między gospodarkami najbogatszymi i najbiedniejszymi zaistniała zaś dywergencja. Te wnioski doprowadziły do powstania hipotezy konwergencji klubowej zakładającej występowanie zbieżności wewnątrz grup gospodarek przy jednoczesnej dywergencji pomiędzy poszczególnymi grupami.

Wiek XXI przyniósł rozkwit badań nad konwergencją w krajach Europy. Zbigniew Matkowski i Mariusz Próchniak przeprowadzili analizę konwergencji 8 krajów Europy Środkowej, tj. Polski, Czech, Słowacji, Litwy, Łotwy, Estonii, Węgier i Słowenii w stosunku do 15 członków tzw. starej Unii ${ }^{15}$. Pod uwagę wzięto stosunkowo krótki okres obejmujący lata 1993-2001. Autorzy wykazali istnienie silnej konwergencji typu $\beta$ zarówno $\mathrm{w}$ odniesieniu do poszczególnych krajów, jak i całego regionu. Nowe kraje członkowskie cechowały się w tym okresie wyraźnie szybszym tempem wzrostu gospodarczego, niż pozostali członkowie wspólnoty. Ville Kaitila w swych badaniach nad konwergencją skoncentrował się na 15 członkach Unii Europejskiej, biorąc pod uwagę kolejne 42 lata, począwszy od 1960 r. ${ }^{16} \mathrm{~W}$ tym wypadku hipoteza konwergencji została również pozytywnie zweryfikowana. W późniejszym okresie powstało bardzo wiele badań koncentrujących się na analizie konwergencji na terenie Europy. Różnią się one zazwyczaj doborem próby badawczej oraz uwzględnianym w analizie okresem. Częstym

12 J.B. De Long, Productivity Growth, Convergence, and Welfare: Comment, „American Economic Review" 78 (1988), nr 5.

13 P.M. Romer, Growth Based on Increasing Returns Due to Specialization, „American Economic Review" 77 (1987), nr 2.

14 T. Kristensen, Development in Rich and Poor Countries, New York 1982.

15 Z. Matkowski, M. Próchniak, Real Economic Convergence in the EU Accession Countries, „RIED Papers and Proceedings" 74 (2004), nr 7.

16 V. Kaitila, Integration and Conditional Convergence in the Enlarged EU Area, „ETLA Discussion Papers. The Research Institute of the Finnish Economy (ETLA)” (2004), nr 935. 
zjawiskiem jest analizowanie zbieżności poziomów dochodu pomiędzy tzw. nowymi i starymi członkami UE.

Za przykład może służyć praca Evy Jelnikar i Urbana Murmayera, którzy potwierdzili konwergencje wewnątrz 25 krajów UE w latach 1995-2007, zaznaczając, iż nastąpiło zbliżenie poziomów dochodu 10 krajów, które dołączyły do wspólnoty w $2004 \mathrm{r}$. w stosunku do 15 dotychczasowych członków $\mathrm{UE}^{17}$. Nieco innych wniosków dostarcza natomiast badanie Mihálya Tamása Borsiego i Norberta Metiu $^{18}$. Opierając się na danych dla 27 krajów UE, wykazali co prawda występowanie procesów zbieżności, aczkolwiek zauważyli istnienie tzw. klubów konwergencji, wewnątrz których zbieżność była szczególnie wysoka. Badanie udowodniło również, iż szczególnie istotną rolę $\mathrm{w}$ formowaniu się klubów konwergencji odegrały powiązania regionalne.

Oprócz prac poświęconych konwergencji w UE w literaturze można znaleźć także analizy skoncentrowane na gospodarkach Europy Środkowo-Wschodniej. Przykładem są badania przeprowadzone przez Próchniaka i Ryszarda Rapackiego, którzy zweryfikowali istnienie konwergencji typu $\beta$ oraz $\sigma^{19}$. Próba badawcza składała się z 12 państw Wspólnoty Niepodległych Państw (WNP), 8 państw Europy Środkowo-Wschodniej należących do UE oraz 7 państw Europy Południowo-Wschodniej. Badania oparto na danych z lat 1990-2005. Badanie to miało wielowariantowy charakter. Weryfikowano hipotezę konwergencji zarówno w całej grupie składającej się z 27 państw, jak również w poszczególnych mniejszych grupach. Oprócz analiz prowadzonych dla całego piętnastoletniego okresu stwierdzano również występowanie procesów zbieżności w krótszych przedziałach czasowych. Rozległość badania nie pozwoliła na wyciągnięcie jasnych wniosków. W większości przyjętych wariantów konwergencja zaszła w grupie państw Europy Środkowo-Wschodniej oraz Południowo-Wschodniej. Brak procesów zbieżności wystąpił w grupie państw WNP. Dženita Šiljak przeprowadziła analizę konwergencji w grupie państw postsocjalistycznych ${ }^{20}$. W sumie badaniem zostały objęte 23 państwa Europy Wschodniej, Środkowo-Wschodniej oraz Południowej. Badanie dotyczyło lat 2004-2016. Wykazało ono występowanie procesów zbieżności państw bałkańskich oraz państw Europy Wschodniej w odniesieniu do 11 krajów Europy Środkowo-Wschodniej będących członkami UE.

17 E. Jelnikar, U. Murmayer, Convergence in Europe Empirical Analysis on Two Groups of Countries of the European Union, „Human and Economic Resources Proceedings Book” (2006), nr 246.

18 M.T. Borsi, N. Metiu, The evolution of economic convergence in the European Union, „Empirical Economics" 48 (2015), nr 2.

19 M. Próchniak, R. Rapacki, Konwergencja beta i sigma $w$ krajach postsocjalistycznych $w$ latach 1990-2005, „Bank i Kredyt” (2007), nr 8-9.

${ }^{20}$ D. Siljak, S.G. Nagy, The Effects of the Crisis on the Convergence Process of the Western Balkan Countries towards the European Union, "Society and Economy” 40 (2018), nr 1. 


\section{Metodologia badawcza}

Grupę badawczą tworzy 15 krajów powstałych po rozpadzie Związku Radzieckiego, czyli Armenia, Azerbejdżan, Białoruś, Estonia, Gruzja, Kazachstan, Kirgistan, Litwa, Łotwa, Mołdawia, Rosja, Tadżykistan, Turkmenistan, Ukraina oraz Uzbekistan. Prace przytoczone w przeglądzie literatury, poświęcone badaniom konwergencji w krajach Europy, nie zawierały weryfikacji hipotezy zbieżności dochodów w tak skonstruowanej grupie krajów. Najbardziej zbliżoną grupę tworzą kraje WNP. Wspólnota liczy obecnie 9 członków oraz 1 państwo stowarzyszone. W pracy Próchniaka i Rapackiego, opublikowanej w 2007 r., prócz tych 10 krajów w próbie badawczej uwzględniono Gruzję i Ukrainę, które opuściły organizację kolejno w 2009 i 2018 r. Jednak nawet przed opuszczeniem WNP przez te 2 państwa do organizacji nigdy nie należały wszystkie kraje powstałe po rozpadzie ZSRR. Próba uwzględniona w niniejszym badaniu jest więc szersza, gdyż poza krajami członkowskimi WNP zawiera również trzy kraje bałtyckie, tj. Litwę, Łotwę i Estonię. Badanie dotyczy okresu obejmującego ostatnią dekadę XX w. oraz pierwsze dziesięciolecie XXI w. Rozpad Związku Radzieckiego formalnie nastąpił w $1991 \mathrm{r}$. Za punkt bazowy dla analizy przyjęto więc rok wcześniejszy, stanowiący de facto ostatni pełny rok istnienia ZSRR. Analizy dotyczące kolejnego okresu 1991-1995 są obarczone ryzykiem, ponieważ w okresie tym nastąpił rozkład służb statystycznych w badanych krajach, co powoduje zmniejszenie wiarygodności danych z tego okresu. Zdecydowano się jednak na rozpoczęcie analizy od 1991 r., ponieważ zmiany poziomu PKB w przypadku większości badanych krajów były w pierwszych kilku latach po rozpadzie ZSRR tak głębokie, że ich pominięcie mogłoby prowadzić do wyciągnięcia błędnych wniosków co do ogólnej oceny przebiegu procesów transformacji gospodarczej w tych krajach. Rozpoczęcie analizy od 1992 bądź np. 1993 r. pozwoliłoby na operowanie bardziej wiarygodnymi danymi, nie przyzwalając jednocześnie na uwzględnienie czasu największego załamania gospodarczego, które bezpośrednio oddziaływało na kształtowanie się wielkości PKB per capita w dalszej części analizowanego okresu.

Okres objęty badaniem został podzielony na równe pięcio- i dziesięcioletnie etapy. Nie zdecydowano się na zastosowanie innego podejścia, ponieważ nie stwierdzono występowania żadnego punktu w badanym horyzoncie czasowym, który mógłby stanowić np. moment zwrotny dla większości analizowanych krajów, co uzasadniałoby wyróżnienie dwóch podokresów przed i po danym roku. Dzieje się tak dlatego, iż wyniki gospodarcze 15 badanych państw były w analizowanym okresie bardzo zróżnicowane. W przypadku Armenii i Estonii nieprzerwany spadek PKB per capita zakończył się już w 1993 r. Na przeciwległym biegunie znalazła się zaś Ukraina, odnotowująca recesję do 1998 r. Dla 6 krajów koniec recesji nastąpił w 1995 r., dla 2 - w 1994 r., natomiast w 4 krajach nieprzerwana recesja zakończyła się w 1996 r. Nie znaleziono więc argumentów wskazujących na zastosowanie odmiennego podziału analizowanego okresu. 
Dane użyte $\mathrm{w}$ niniejszym badaniu zostały opracowane na podstawie Penn World Table wersja 9.0. Pozyskanie danych do badania wymagało sięgnięcia do ogólnodostępnych opracowań grupujących dane z zakresu kształtowania się poziomu PKB per capita w ujęciu historycznym uwzględniającym kraje wykorzystane w badaniu. Oprócz serii opracowań, pt. „Penn World Table”, alternatywnym źródłem danych może być np. Maddison Project Database (MPD) 2018. Nie sposób jednak rozstrzygnąć, które opracowanie należy obdarzyć większym zaufaniem.

Tabela 1. Początkowy poziom PKB per capita oraz stopy wzrostu w poszczególnych okresach w 15 analizowanych krajach

\begin{tabular}{|c|c|c|c|c|c|c|c|c|}
\hline \multirow[b]{2}{*}{ Państwo } & \multirow[b]{2}{*}{$\begin{array}{c}\text { Poziom } \\
\text { PKB per } \\
\text { capita } \\
\text { w } 1990 \text { r. }\end{array}$} & \multicolumn{7}{|c|}{ Średnioroczna stopa wzrostu w okresie } \\
\hline & & $\frac{\frac{\pi}{2}}{\frac{1}{2}}$ & 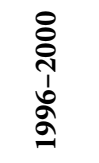 & 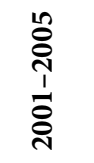 & 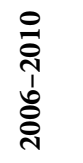 & \begin{tabular}{l}
8 \\
\multirow{2}{1}{} \\
$\frac{1}{2}$
\end{tabular} & 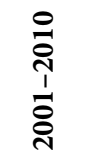 & $\begin{array}{l}\stackrel{0}{2} \\
\frac{1}{1} \\
\frac{1}{2}\end{array}$ \\
\hline Armenia & $4571 \$$ & $-10,9 \%$ & $5,9 \%$ & $12,2 \%$ & $4,1 \%$ & $-2,5 \%$ & $8,2 \%$ & $2,9 \%$ \\
\hline Azerbejdżan & $9028 \$$ & $-18,9 \%$ & $5,9 \%$ & $11,3 \%$ & $14 \%$ & $-6,5 \%$ & $12,6 \%$ & $3,1 \%$ \\
\hline Białoruś & $8736 \$$ & $-8,4 \%$ & $6,5 \%$ & $7,8 \%$ & $7,3 \%$ & $-0,9 \%$ & $7,6 \%$ & $3,3 \%$ \\
\hline Estonia & $13360 \$$ & $-5,4 \%$ & $6,4 \%$ & $7,5 \%$ & $0 \%$ & $0,5 \%$ & $3,7 \%$ & $2,1 \%$ \\
\hline Gruzja & $9248 \$$ & $-23,7 \%$ & $7 \%$ & $8,2 \%$ & $6,2 \%$ & $-8,3 \%$ & $7,2 \%$ & $-0,6 \%$ \\
\hline Kazachstan & $12922 \$$ & $-9 \%$ & $3,7 \%$ & $9,2 \%$ & $5 \%$ & $-2,6 \%$ & $7,1 \%$ & $2,2 \%$ \\
\hline Kirgistan & $4960 \$$ & $-14, \%$ & $3,9 \%$ & $3,1 \%$ & $3 \%$ & $-5,3 \%$ & $3 \%$ & $-1,1 \%$ \\
\hline Litwa & $14225 \$$ & $-10,5 \%$ & $5,4 \%$ & $8,2 \%$ & $2,5 \%$ & $-2,6 \%$ & $5,4 \%$ & $1,4 \%$ \\
\hline Łotwa & $14543 \$$ & $-12,7 \%$ & $6 \%$ & $9,1 \%$ & $0,8 \%$ & $-3,3 \%$ & $5 \%$ & $0,8 \%$ \\
\hline Mołdawia & $7456 \$$ & $18,5 \%$ & $-1,9 \%$ & $7,1 \%$ & $3,5 \%$ & $-10,2 \%$ & $5,3 \%$ & $-2,4 \%$ \\
\hline Rosja & 19988 \$ & $-9,6 \%$ & $1,8 \%$ & $6,3 \%$ & $3,5 \%$ & $-3,9 \%$ & $4,9 \%$ & $0,5 \%$ \\
\hline Tadżykistan & $5376 \$$ & $-21,1 \%$ & $-1,3 \%$ & $7,3 \%$ & $4,1 \%$ & $-11,2 \%$ & $5,7 \%$ & $-2,7 \%$ \\
\hline Turkmenistan & $12145 \$$ & $-11,8 \%$ & $2,9 \%$ & $3,9 \%$ & $8,7 \%$ & $-4,5 \%$ & $6,3 \%$ & $0,9 \%$ \\
\hline Ukraina & $13204 \$$ & $-14,6 \%$ & $-1,2 \%$ & $8,2 \%$ & $1,5 \%$ & $-7,9 \%$ & $4,9 \%$ & $-1,5 \%$ \\
\hline Uzbekistan & $4824 \$$ & $-6,2 \%$ & $2,3 \%$ & $4,3 \%$ & $6,9 \%$ & $-1,9 \%$ & $5,6 \%$ & $1,8 \%$ \\
\hline
\end{tabular}

Opracowanie własne na podstawie Penn World Table 9.0.

W powyższej tabeli zaprezentowano dane będące podstawą do weryfikacji hipotezy konwergencji absolutnej w rozpatrywanej próbie. Na bazie danych w obszarze realnego PKB i kształtowania się wielkości populacji w poszczególnych krajach dokonano kalkulacji PKB per capita dla całego badanego okresu. Za miernik w obszarze PKB przyjęto wartości PKB per capita ważonego parytetem siły nabywczej, wyrażonego w cenach stałych z 2011 r. Tym samym wszelkie kalkulacje zmienności poziomu produkcji prezentowane $\mathrm{w}$ artykule mają charakter realny, a nie nominalny. 
Opracowanie danych $\mathrm{w}$ taki sposób umożliwiło wyznaczenie stóp wzrostu PKB per capita w każdym roku, jak również średnich stóp wzrostu dla całego badanego okresu oraz krótszych podokresów. Kalkulacja średnich stóp wzrostu została dokonana na podstawie wzoru $\frac{1}{T} \ln \frac{Y_{i T}}{Y_{i 0}}$.

Weryfikacja hipotezy o występowaniu konwergencji typu $\beta$ opiera się na skonstruowaniu równania regresji i estymacji jego parametrów, w którym zmienną objaśnianą stanowi średnia stopa wzrostu w danym okresie, a zmienną objaśniającą - poziom dochodu per capita na początku okresu. Następnie dokonywany jest test Fishera-Snedecora celem weryfikacji istotności statystycznej parametrów równania. O występowaniu zbieżności świadczy ujemna wartość parametru znajdująca się przy zmiennej objaśniającej, jaką jest logarytm naturalny poziomu dochodu per capita. W przypadku stwierdzenia istnienia konwergencji, w oparciu o zaprezentowany wcześniej wzór, wyznacza się jej tempo oznaczone współczynnikiem $\beta$. Weryfikacji hipotezy o występowaniu konwergencji typu $\sigma$ dokonuje się za pomocą analizy zmian wartości odchyleń standardowych dochodów per capita w badanej grupie w ciągu analizowanego okresu.

\section{Wyniki badania}

W roku 1990, stanowiącym punkt bazowy dla analizy, poziom zróżnicowania dochodów per capita pomiędzy poszczególnymi republikami Związku Radzieckiego był znaczący. Do najbiedniejszych możemy zaliczyć cztery republiki położone w środkowej Azji: Armeńską SRR, Tadżycką SRR, Uzbecką SRR oraz Kirgiską SRR. Najbogatszą republiką była zaś Rosyjska SRR. Jako relatywnie zamożne można również potraktować republiki bałtyckie, tj. Estońską SRR, Litewską SRR, Łotewską SRR oraz Ukraińską i Kazachską SRR. Rozpiętość między poziomem PKB per capita najbogatszej Rosyjskiej SRR i najbiedniejszej Armeńskiej SRR była ponad czterokrotna.

Tabela 2. Wyniki regresji dla całego okresu

\begin{tabular}{|c|c|c|c|c|c|c|c|}
\hline Okres & $\boldsymbol{\alpha}_{\mathbf{0}}$ & $\boldsymbol{\alpha}_{\mathbf{1}}$ & Statystyka F & Istotność $\mathbf{F}$ & $\boldsymbol{R}^{\mathbf{2}}$ & Zbieżność & $\boldsymbol{\beta}$ \\
\hline $1991-2010$ & $-0,44$ & 0,06 & 0,234 & 0,636 & 0,018 & Nie & - \\
\hline
\end{tabular}

Opracowanie własne.

W pierwszym wariancie analizy stworzono równanie regresji dla całego badanego okresu. Zostały one zaprezentowane w tabeli 2 . Współczynnik $\alpha_{1}$ jest dodatni. Świadczy to o braku występowania konwergencji typu $\beta \mathrm{w}$ analizowanym okresie. Otrzymane wyniki wskazują na pojawienie się dywergencji pomiędzy badanymi gospodarkami. Należy zwrócić uwagę na bardzo słabe własności statystyczne równania regresji, co świadczy o bardzo słabej zależności stóp wzrostu od początkowego 
Wykres 1. Tempo wzrostu gospodarczego w okresie 1991-2010 a początkowy poziom PKB per capita

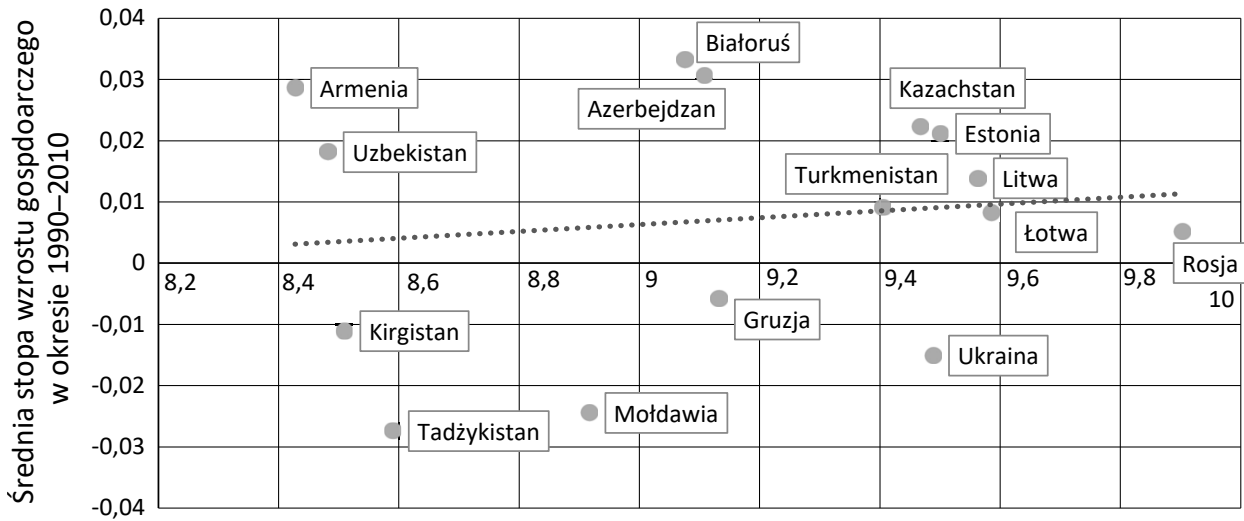

Wartość logarytmu naturalnego poziomu PKB per capita

Opracowanie własne na podstawie Penn World Table 9.0.

poziomu dochodu per capita. Opisywane zależności ilustruje również wykres. Linia trendu ma nachylenie dodatnie, co wyklucza występowanie konwergencji.

W przypadku 5 z 15 państw byłego ZSRR poziom PKB per capita w 2010 r. okazał się niższy niż w 1990 r., co oznacza, iż w badanym okresie średnioroczne tempo wzrostu było ujemne. Ujemne tempo wzrostu w tym okresie odnotowały 2 z 4 państw wskazanych wcześniej jako najbiedniejsze w punkcie startu. Najwyższe ponad trzyprocentowe tempo wzrostu nastąpiło na Białorusi i w Azerbejdżanie. Relatywnie szybko rozwijały się stosunkowo bogate kraje, takie jak Estonia i Kazachstan, ale również najbiedniejsza w 1990 r. Armenia. Po upływie 20 lat najbogatszym krajem pozostała Rosja. Zmniejszył się jednak dystans do następnych w kolejce państw bałtyckich. Znaczny awans odnotowały Azerbejdżan oraz Kazachstan. Ich szybki rozwój opierał się w znacznej mierze na wydobyciu surowców naturalnych. Spośród państw zaliczanych w 1990 r. do grupy najbiedniejszych jedynie wyniki gospodarcze Armenii można uznać za zadowalające. Największy regres odnotowały Ukraina, Mołdawia oraz Tadżykistan. To właśnie Tadżykistan stał się w 2010 r. najbiedniejszym krajem w analizowanej grupie. Rozpiętość poziomów PKB per capita w 2010 r. pomiędzy najbogatszą Rosją a najbiedniejszym $\mathrm{w}$ tym momencie Tadżykistanem była ponad sześcioipółkrotna.

Tabela 3 przedstawia wyniki regresji dla sześciu podokresów. Badane 20 lat podzielono na dwa okresy dziesięcioletnie oraz na cztery okresy pięcioletnie. Moim zdaniem takie ujęcie pozwala na lepsze zrozumienie procesów rozwoju gospodarek państw byłego Związku Radzieckiego w dwóch pierwszych dekadach po odzyskaniu suwerenności.

W latach 1991-1995 15 krajów powstałych po upadku ZSRR odnotowało spadek poziomu PKB per capita. Najgłębszej recesji doświadczyły Gruzja, Tadżykistan oraz Mołdawia. Bardzo złe wyniki gospodarcze najbiedniejszych państw, przy 
Tabela 3. Wyniki regresji dla danych podokresów

\begin{tabular}{|c|c|c|c|c|c|c|c|}
\hline Okres & $\boldsymbol{\alpha}_{\mathbf{0}}$ & $\boldsymbol{\alpha}_{\mathbf{1}}$ & Statystyka F & Istotność $\mathbf{F}$ & $\boldsymbol{R}^{\mathbf{2}}$ & Zbieżność & $\boldsymbol{\beta}$ \\
\hline $1991-2000$ & $-0,202$ & 0,017 & 0,739 & 0,406 & 0,054 & Nie & - \\
\hline $2001-2010$ & 0,101 & $-0,004$ & 0,215 & 0,651 & 0,016 & Tak & 0,0041 \\
\hline $1991-1995$ & $-0,373$ & 0,026 & 0,717 & 0,413 & 0,052 & Nie & - \\
\hline $1996-2000$ & $-0,52$ & 0,01 & 0,547 & 0,473 & 0,04 & Nie & - \\
\hline $2001-2005$ & 0,049 & 0,003 & 0,083 & 0,777 & 0,006 & Nie & - \\
\hline $2006-2010$ & 0,141 & $-0,01$ & 0,509 & 0,488 & 0,038 & Tak & 0,01 \\
\hline
\end{tabular}

Opracowanie własne.

jednoczesnym występowaniu mniejszego spadku produkcji per capita $\mathrm{w}$ bogatszych państwach bałtyckich, Kazachstanie oraz najbogatszej w początkowym roku Rosji, spowodowały powstanie dywergencji poziomów dochodu per capita. Świadczą o tym otrzymane wyniki regresji. Dodatni współczynnik $\alpha_{1}$ informuje o braku konwergencji typu $\beta$. W ciągu następnych pięciu lat mieliśmy do czynienia z wyraźnym ożywieniem gospodarczym $\mathrm{w}$ badanej grupie państw. W przypadku wszystkich 15 krajów średnia stopa wzrostu w tym okresie była wyższa niż w poprzednich pięciu latach. Jednak trzy państwa, tj. Ukraina, Mołdawia i Tadżykistan, zanotowały w tym czasie spadek produkcji per capita. Na ścieżkę relatywnie szybkiego wzrostu wkroczyły zaś trzy państwa bałtyckie. Wśród krajów, które w punkcie początkowym zaliczały się do najuboższych, najlepiej radziła sobie Armenia. Gorsze wyniki odnotowały gospodarki Kirgistanu i Uzbekistanu. W szczególny sposób tendencje do dywergencji potęgowała przedłużająca się recesja w ubogim Tadżykistanie. W okresie 2001-2005 wszystkie badane gospodarki odnotowały wzrost PKB per capita. Najwyższy przyrost produkcji osiągnęły gospodarki państw kaukaskich, tj. Armenii oraz Azerbejdżanu. Wysokie stopy wzrostu miały w tym okresie również państwa bałtyckie. Wyraźne ożywienie nastąpiło w przypadku gospodarki Tadżykistanu. Znacznie poniżej średniej dla całej badanej grupy rozwijały się jednak inne uboższe kraje, takie jak Uzbekistan i Kirgistan. Zarówno w okresie 1996-2000, jak i latach 2001-2005 w badanej grupie gospodarek wystąpiła dywergencja poziomów PKB per capita, co potwierdzają otrzymane parametry równań regresji. Odwrócenie tendencji $\mathrm{w}$ zakresie dywergencji nastąpiło dopiero $\mathrm{w}$ ostatnim $\mathrm{z}$ analizowanych podokresów. Na lata 2006-2010 przypadły wybuch i pierwsza faza ogólnoświatowego kryzysu finansowego. W największym stopniu tempo wzrostu PKB obniżyło się w przypadku Litwy, Łotwy i Estonii. W wolnym tempie rozwijała się również Rosja. W tym okresie tempo wzrostu PKB państw zaliczanych do uboższych było wyraźnie wyższe od średniej dla całej grupy. Wyniki regresji dla okresu 2001-2005 potwierdzają istnienie konwergencji typu $\beta$. Wartości statystyczne równania są jednak bardzo słabe. Relatywnie wolne jest również tempo konwergencji, wynosząc 0,01 .

Drugi wariant badania został oparty na podziale 20 lat na dwa okresy dziesięcioletnie. Na pierwszy okres, obejmujący lata 1991-2000, składały się dwa 
wcześniej analizowane etapy pięcioletnie, w przypadku których stwierdzono brak konwergencji typu $\beta$ i zaistnienie dywergencji w badanej grupie gospodarek. Tym samym logicznym wnioskiem, potwierdzonym wynikami analizy regresji, jest brak $\beta$-konwergencji $\mathrm{w}$ całym dziesięcioletnim okresie. W przypadku lat 2001-2010 mamy do czynienia $z$ bardziej skomplikowaną sytuacją, gdyż na okres ten składają się dwa pięcioletnie podokresy, gdzie w przypadku pierwszego stwierdzono występowanie dywergencji, natomiast w podokresie drugim nastąpiła konwergencja gospodarek. Analiza regresji przeprowadzona dla całego dziesięcioletniego okresu wykazała występowanie zbieżności, o czym świadczy ujemna wartość współczynnika $\alpha_{1}$. Tempo zbieżności jest jednak bardzo wolne.

Tabela 4. Odchylenie standardowe logarytmu naturalnego PKB per capita

\begin{tabular}{|c|c|c|c|c|c|c|c|c|c|}
\hline $\mathbf{1 9 9 1}$ & $\mathbf{1 9 9 2}$ & $\mathbf{1 9 9 3}$ & $\mathbf{1 9 9 4}$ & $\mathbf{1 9 9 5}$ & $\mathbf{1 9 9 6}$ & $\mathbf{1 9 9 7}$ & $\mathbf{1 9 9 8}$ & $\mathbf{1 9 9 9}$ & $\mathbf{2 0 0 0}$ \\
\hline 0,4621 & 0,5342 & 0,5557 & 0,5691 & 0,5735 & 0,5934 & 0,5993 & 0,6012 & 0,6067 & 0,6200 \\
\hline $\mathbf{2 0 0 1}$ & $\mathbf{2 0 0 2}$ & $\mathbf{2 0 0 3}$ & $\mathbf{2 0 0 4}$ & $\mathbf{2 0 0 5}$ & $\mathbf{2 0 0 6}$ & $\mathbf{2 0 0 7}$ & $\mathbf{2 0 0 8}$ & $\mathbf{2 0 0 9}$ & $\mathbf{2 0 1 0}$ \\
\hline 0,6229 & 0,6227 & 0,6247 & 0,6275 & 0,6412 & 0,6620 & 0,6757 & 0,6582 & 0,6303 & 0,6307 \\
\hline
\end{tabular}

Opracowanie własne.

Drugim etapem analizy procesu zbieżności gospodarek państw byłego Związku Radzieckiego jest weryfikacja hipotezy konwergencji typu $\sigma$. Tabela 4 przedstawia kształtowanie się wartości odchylenia standardowego logarytmu naturalnego PKB per capita 15 analizowanych krajów w całym rozpatrywanym okresie. Stwierdzenie braku występowania $\beta$-konwergencji $\mathrm{w}$ trzech pierwszych podokresach implikuje automatycznie brak konwergencji typu $\sigma$. Brak $\sigma$-konwergencji potwierdza widoczny $\mathrm{w}$ tabeli systematyczny wzrost poziomu odchylenia standardowego $\mathrm{w}$ ciągu pierwszych 15 lat. Weryfikacja hipotezy konwergencji typu $\sigma$ jest sensowna jedynie dla lat 2006-2010. W okresie tym mamy do czynienia $\mathrm{z}$ obniżeniem się wartości odchylenia standardowego. Celem zobrazowania zależności polegającej na zmniejszaniu się odchylenia standardowego z biegiem czasu konstruowane jest równanie regresji, w którym zmienną objaśnianą stanowi odchylenie standardowe logarytmu naturalnego, a zmienną objaśniającą - kolejne upływające lata.

Tabela 5. Wyniki regresji dla okresu 2006-2010

\begin{tabular}{|c|c|c|c|c|c|}
\hline $\boldsymbol{\alpha}_{\mathbf{0}}$ & $\boldsymbol{\alpha}_{\mathbf{1}}$ & Statystyka F & Istotność F & $\boldsymbol{R}^{\mathbf{2}}$ & Zbieżność \\
\hline 0,684 & $-0,011$ & 7,659 & 0,07 & 0,719 & Tak \\
\hline
\end{tabular}

Opracowanie własne.

W tabeli 5 zaprezentowano wyniki analizy regresji. Parametry równania regresji potwierdzają występowanie zbieżności typu $\sigma$. Wskazuje na to ujemna wartość współczynnika $\alpha_{1}$. Własności statystyczne równania są znacznie lepsze niż te uzyskane przy weryfikacji konwergencji typu $\beta$. 


\section{Podsumowanie}

Analiza procesów rozwojowych 15 państw powstałych po upadku ZSRR przeczy hipotezie o pojawieniu się zbieżności poziomów dochodu. Występowanie konwergencji typu $\beta$ zostało pozytywnie zweryfikowane jedynie w przypadku ostatniego rozpatrywanego podokresu, przy czym własności statystyczne przeprowadzonej regresji były bardzo słabe. W pozostałych podokresach, jak również w całym analizowanym okresie doszło do dywergencji poziomów PKB per capita. Świadczą o tym negatywna weryfikacja hipotezy konwergencji $\beta$, jak również wzrost odchylenia standardowego logarytmu naturalnego poziomu PKB per capita, co wskazuje na brak konwergencji typu $\sigma$. Weryfikacja hipotezy konwergencji $\sigma$ została przeprowadzona jedynie dla okresu, gdzie stwierdzono występowanie konwergencji $\beta$. Brak konwergencji typu $\beta$ z definicji wyklucza istnienie konwergencji typu $\sigma$.

Rozpad systemu gospodarki centralnie planowanej i transformacja systemu gospodarczego w całej Europie Środkowo-Wschodniej stanowią unikalne wydarzenie z perspektywy całej historii gospodarczej świata. Brak analogii z przeszłości był czynnikiem dodatkowo komplikującym skuteczne przejście z systemu gospodarki centralnie planowanej do systemu gospodarki rynkowej. W przypadku krajów powstałych po rozpadzie ZSRR rozwój gospodarczy w latach 1991-2010 trudno uznać za zadowalający. Tylko 2 z 15 krajów odnotowały w tym okresie średnioroczną stopę wzrostu na poziomie przekraczającym 3\%. Trzy kolejne osiągnęły średnie stopy wzrostu w przedziale $2-3 \%$. $Z$ tych pięciu najszybciej rozwijających się gospodarek dwie, tj. Kazachstan i Azerbejdżan, swój rozwój zawdzięczają w głównej mierze wydobyciu i eksportowi surowców naturalnych. Bardzo negatywnym zjawiskiem jest spadek poziomu PKB per capita aż w 5 z 15 krajów. Do zaistnienia zjawiska dywergencji w największym stopniu przyczyniły się bezwzględny spadek poziomu PKB per capita w Tadżykistanie, Mołdawii, Kirgistanie oraz niski wzrost PKB w Uzbekistanie. Wszystkie te kraje na początku 1990 r. miały poziom PKB per capita wyraźnie poniżej średniej dla całego ZSRR.

\section{Convergence in Former Soviet Union Countries over the Period 1991-2010}

\section{Abstract}

This article is devoted to verification of convergence hypothesis it the group of 15 former Soviet Union countries. First section of article includes overview of theoretical concepts of convergence. Author enumerates and characterizes different types of convergence focusing particularly on $\beta$-convergence and $\sigma$-convergence, which are verified in next part of article. Next section presents an overview of researches concerning the subject of convergence. In methodological section author describes research methodology and presents research sample. Empirical section includes presentation of the results of the researches which were conducted 
in order to verify convergence hypothesis in analyzed sample. Author carries out regression analysis and describes its results. The analysis was conducted for whole period 1990-2010 and for some shorter subperiods.

\section{Конвергенция в странах бывшего Советского Союза в период 1991-2010}

\section{Аннотация}

Статья посвящена проверке гипотезы о конвергенции в группе 15 бывших советских республик. В первой части статьи проводится обзор теоретических концепций конвергенции. Автор перечисляет и характеризует разные типы конвергенции, сосредоточиваясь особенно на $\beta$-конвергенции и $\sigma$-конвергенции, которые проверяются в следующей части статьи. Очередная часть является обзором исследований, касающихся вопроса конвергенции. В методологическом разделе автор описывает методологию исследования и представляет образец для исследований. Эмпирический раздел включает в себя презентацию результатов исследований, проведенных с целью проверки гипотезы о конвергенции в анализируемом образце. Автор проводит регрессионный анализ и описывает его результаты. Анализ был проведен для всего периода 1991-2010 гг. и для нескольких более коротких этапов.

\section{Bibliografia}

Barro R.J., Economic Growth in a Cross Section of Countries, „Quarterly Journal of Economics” 106 (1991), nr 2.

Barro R.J., Sala-i-Martin X.X., Convergence, „Journal of Political Economy” 100 (1992), nr 2.

Baumol W.J., Productivity Growth, Convergence, and Welfare, "American Economic Review” 76 (1986), nr 5.

Borsi M.T., Metiu N., The evolution of economic convergence in the European Union, „Empirical Economics" 48 (2015), nr 2.

De Long B., Productivity Growth, Convergence, and Welfare: Comment, „American Economic Review" 78 (1988), nr 5.

Jelnikar E., Murmayer U., Convergence in Europe Empirical Analysis on Two Groups of Countries of the European Union, „Human and Economic Resources Proceedings Book” (2006), nr 246.

Kaitila V., Integration and Conditional Convergence in the Enlarged EU Area, „ETLA Discussion Papers. The Research Institute of the Finnish Economy (ETLA)” (2004), nr 935.

Kristensen T., Development in Rich and Poor Countries, New York 1982.

Lucas R.E., Some Macroeconomics for the 21st Century, „Journal of Economic Perspective” (2000), nr 14 (1).

Mankiw N.G., Romer D., Weil D.N., A contribution to the Empirics of Economic Growth, „Quarterly Journal of Economics" (1992), nr 107.

Matkowski Z., Próchniak M., Real Economic Convergence in the EU Accession Countries, „RIED Papers and Proceedings" 74 (2004), nr 7.

Pigliaru F., Detecting Technological Catch-Up in Economic convergence, „Metroeconomica” (2003), nr 54 (2/3).

Próchniak M., Rapacki R., Beta and Sigma Convergence in the Post-Socialist Countries in 19902005, „Bank i Kredyt” (2007), nr 8-9. 
Romer D., Makroekonomia dla zaawansowanych, Warszawa 2000.

Romer P.M., Growth Based on Increasing Returns Due to Specialization, „American Economic Review" 77 (1987), nr 2.

Sala-i-Martin X.X, Cross-sectional Regressions and the Empirics of Economic Growth, „European Economic Review" 38 (1994), nr 3-4.

Sala-i-Martin X.X., On Growth and States, Cambridge 1990.

Sala-i-Martin X.X., The Classical Approach to Convergence Analysis, „Economic Journal” 106 (1996), nr 437.

Siljak D., Nagy S.G., The Effects of the Crisis on the Convergence Process of the Western Balkan Countries towards the European Union, „Society and Economy” 40 (2018), nr 1.

Wiktor Bloch, mgr, asystent w Katedrze Funkcjonowania Gospodarki na Wydziale Ekonomiczno-Socjologicznym Uniwersytetu Łódzkiego. Specjalizuje się w tematyce wzrostu i rozwoju gospodarczego, konwergencji gospodarek oraz pułapek rozwojowych (wiktor.bloch@uni.lodz.pl).

Wiktor Błoch, MA, assistant at the Department of Economic Mechanisms of the Faculty of Economics and Sociology, University of Lodz. He specialises in the economic growth and development, convergence of economies, and development traps (wiktor.bloch@uni.lodz.pl). 